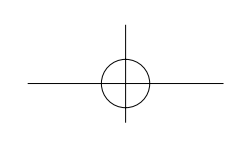

\title{
The Rise and Fall of Corporate Sports Programs
}

\author{
Masahiko SAWANO \\ Hokkai Gakuen University
}

\section{INTRODUCTION}

$\mathrm{T}$

OODAY, private enterprises support sports throughout the world. As sport events such as the FIFA World Cup and the summer and winter Olympic Games have become highly valued and widely viewed content in mass media, companies can expect a large advertising effect through the mass media coverage of the athletes, teams, and sports events that they sponsor. However, the athletes who can benefit from these sponsorships are limited to those who are covered extensively by mass media. On the other hand, athletes of sports with limited public interest and those who have yet to develop into sport stars do not deserve such corporate support and no matter how well they perform or how bright their future is, these athletes will not be supported. For example, the Japanese national team for women's field hockey had won the right to compete in the summer Olympics in Athens and was considered a medal favorite. Yet they had significant difficulties in securing corporate sponsorships, and it was rumored that they may have to withdraw from the competition. Even when the right type of athlete or team can be identified, corporate support is influenced by general economic conditions. When the economy is booming, many companies would offer to support them, while in times of economic hardship, the amount of support would decrease. From the perspective of athletes and sports teams, such rise and fall in corporate sponsorship according to economic boom and bust present significant difficulties. 
One significant characteristics of corporate sponsorship of sports in Japan is that companies not only provided funding for athletes and teams but actually operated teams composed of employees. In this article, "corporate sports" is defined as sports activities in which a company employs athletes as regular employees and assigns practice and competition as a part of their work duties or after work activities with the financial and material support of the company. Companies have supported corporate sports without regard to profit making, and any gains that resulted from such support were considered incidental.

One advantage of corporate sports is that because athletes are employees, they can continue to work as employees of the same company after they retire from competition. Although some athleteemployees leave the company when they retire from competition and choose a different career, such as joining their family business, about half of the athlete-employees in corporate sports remain with the same company after retirement from competition and become a valuable member of its workforce. Athlete-employees and their support staff become valuable employees to the company as they develop skills through sports that can be applied to the workplace. For example, they develop time management skills as they balance work and sports, or develop a unique social network as they participate in national and international competition and meet people they would not otherwise meet in their work roles. For these reasons, corporate sports have given young people the opportunity to participate in competitive sports after completing their education. Given the popular notion that learning new skills become more difficult after age thirty and considering the issues surrounding the post-retirement career of athletes whose sole focus was on competitive sports into their thirties, this system of employeeathletes benefits the athletes as well as the company. Although some have criticized this system as taking advantage of the athlete and throwing them away once their competitive career is over, the postretirement period is much longer and even an Olympic gold medalist has no guarantees for life after retirement from competition without such a system.
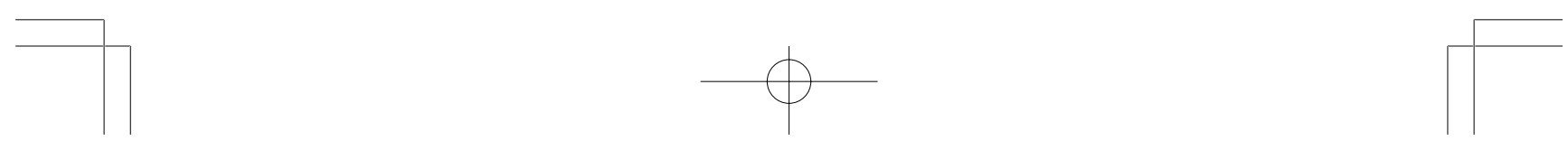


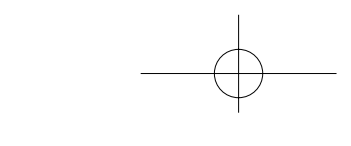

\section{THE ORIGINS OF CORPORATE SPORTS ${ }^{1}$}

Corporate support of employees' sports activities in the form of financial contribution to these activities by the company as a part of its human resource management policies exist in many countries throughout the world, including Korea, China, Southeast Asia, as well as Germany and Scandinavia. In the past, American companies actively supported sports in these ways. But only in Japan have so many companies supported such activities of its employees and included sports in the domain of its business activities. In fact, the national infrastructure to support sports depends heavily on this system. How did Japan come to have such a unique system for supporting sports? This section considers this question.

Japan's system of corporate sports developed as a part of the human resource management system. There are two main patterns of development: the first can be called the employee welfare and benefits type, and the second can be called the employee education and training type. The first type is related primarily to the development of male team sports such as baseball and rugby, for example at Yawata Steel Works [Yawata Seitetsujo]. ${ }^{2}$ The most prominent example of the second type is women's volleyball based in textile factories.

Yawata Steel Works was founded in 1901 as a government operated, modern, western-style steel mill. Its baseball team was founded in 1924 as a result of a baseball game against a local middle school. In the midst of the economic slump that followed the end of World War I, the relationship between the management and the labor unions was very contentious, and baseball was just beginning to be popular as a recreational activity for the mill workers. A baseball team selected from the steel mill workers played a game against a local middle school team. The game was very tight into the late innings when the steel mill team

1. This section is a summary of Masahiko Sawano, Kigyō supōtsu no eikō to zasetsu [The rise and fall of corporate sports] (Tokyo: Seikyūsha, 2004), Chapter 3. On women's volleyball, see Masahiko Sawano, "Soshikiryoku to chiiki e no kakawari wo takameru kigyō no supōtsu [Corporate sports that increase organizational capacity and involvement in local community]," Shōkō Jānaru 33:2 (2007): 14-17.

2. Yawata Steel Works was privatized in 1934. It is now a part of Nippon Steel Corporation [Shin Nihon Seitetsu Kabushiki Kaisha]. 
scored a run, and a worker who was a strong labor union supporter jumped up and cheered with great joy. The human resource manager took notice of this and formed the steel mill baseball team with the idea that in baseball, the management and labor can share the same purpose.

In the late 1920s Japan, light industry such as textiles had become internationally competitive and heavy industry was about to take off in its growth and development. With rapid industrialization, labor moved from poor, rural, agricultural areas to large cities and suburbs where factories were located. Work conditions in the factories were poor and exploitative, and with the spread of liberal ideas under Taisho Democracy, harsh criticism of factory conditions arose throughout Japan as well as from other countries. In response, the government had promulgated the Factory Law and began to regulate working conditions in factories such as work hours.

Japanese companies in heavy industry and chemicals experienced a war-induced boom during World War I followed by a postwar recession. By the late 1920s they had just about recovered from the recession, and the senior management at these companies was beginning to implement employee welfare and benefit policies in advance of the implementation of the Factory Law in an effort to lessen conflict with labor. In light of these developments, corporate sports garnered attention as an easy and cost effective solution for labor peace. Gymnasiums and athletic fields as recreational facilities for employees and baseball and rugby teams as corporate symbols came to be recognized as elements of the employee welfare and fringe benefit system that can unite labor and management.

Moreover, as it was confirmed that cheering together for the company team at competitions led to positive effects such as increased collective identity, more adherence to work rules, fewer workplace accidents, and higher worker morale, companies and factories throughout Japan began to establish corporate sports teams. Thus, corporate sports became a prototype and a symbol of the extensive employee fringe benefits and welfare that became the hallmark of Japanese-style management after World War II.

The second pattern of development for corporate sports is employee training and education, as exemplified in female textile workers. The Japanese textile mills of late $19^{\text {th }}$ and early $20^{\text {th }}$ centuries relied on girls from rural areas immediately following the completion of compulsory 
education as cheap labor. In the early years of the industry, these workers were untrained and could barely understand the instructions of the factory foremen. But around the turn of the century, factories began to establish supplemental schools within the factory for their workers. As the number of textile factories rapidly increased, new factories began to raid trained workers from nearby factories. Factory managers soon discovered that in order to keep a minimum number of trained workers who could serve as leaders on the factory floor, education was indispensable. Once supplemental schools were established, they discovered that workers who performed well academically also became good workers. Completion of compulsory education, initially set at four years, became commonplace only after the Sino-Japanese War (1898). In 1907, compulsory education was extended to six years. As the educational level of textile workers rose, arts and crafts education was added to supplemental schooling. Arts and crafts education included training in tea ceremony, traditional flower arrangement, traditional singing, and knitting and was considered appropriate preparation for marriage. Eventually, it became customary for the company to be responsible for finding to an appropriate marriage partner for female factory workers.

Long work hours for female workers in the textile mills became even more of a serious social problem than work hours for males. From the perspective of the government slogan Strong Army, Wealthy Nation (fukoku kyohei), motherhood as a source of population growth needed protection. With increased competition for textile products internationally, international competitors such as England and India criticized the working conditions in Japan. As a result, the Japanese government was finally convinced to implement a Factory Law to establish minimum standards in factory working conditions in 1916. With the limits placed on work hours, supplemental schools within factories increased in importance. In addition, workers needed instruction in healthy ways to spend their free time. As a part of physical education and recreation, sports such as volleyball were introduced. ${ }^{3}$

Initially, sports, such as volleyball were played only within the

3. Volleyball was introduced to Japan around this time by the YMCA. 
workplace. As many factories and companies began to incorporate sports, inter-factory and inter-company competition began. The dining rooms in female dormitories were remodeled to serve also as gymnasiums, and workers began to enjoy informal games during their lunch breaks. Although many countries did not encourage women to participate in competitive sports because such public displays were considered unbecoming, in Japan, women's sports enjoyed wide participation even in the prewar years. The Meiji Shrine Games, the precursor to today's annual National Sports Festival [kokumin taiiku taikai], included women's volleyball and basketball in addition to track and field and swimming. Hitomi Kinue's silver medal in the 800 meter dash at the 1928 Olympic Games in Amsterdam was achieved in such context. Moreover, the gold medal in women's volleyball in the 1960 Olympic Games in Tokyo was the culmination of the traditions of female textile workers.

\section{CONDITIONS FOR THE ESTABLISHMENT OF CORPORATE SPORTS}

Industrial Revolution, which began in England, modernized industries such as textiles, coal mining, and steel. By the end of the nineteenth century, industrial structure began to change. A large factor behind this change was the discovery of large petroleum fields and the development of industries based on petroleum such as chemicals, electrical equipment, and automobiles. Management and studies of management developed in conjunction with this and resulted from the growth in size and complication of industrial enterprises.

The end of the nineteenth century was a turning point in many ways. Up until this period, fertilizers and dyes were made of naturally occurring materials. For example, plant materials such as safflower and indigo were used as dyes, but in the latter half of the nineteenth century, synthetic dyes made from petroleum were developed. Because natural dyes could not be produced in large quantities and expensive because of their scarcity, demand for them was limited. However, when dyes could be mass produced in factories, limitations on quantity are removed, and with dramatic reduction in price due to mass production, the demand increased dramatically.

A similar transition took place in the textile industry, as natural raw 
materials such as silk, wool, and cotton, which were limited in production quantity, were supplanted in this period by synthetic fibers such as rayon. Mass production of synthetic fibers dramatically increased production quantity and lowered prices. Such developments made possible the expansion of factories and large-scale, large-quantity production.

Analogous developments followed in metal refining and machinery industries. For example, the automobile was invented by Daimler and Benz in 1885-86. In its early years manufacturers such as Benz produced automobiles on custom orders, designing and building each car after receiving an order from the customer and selling them to the wealthy. In 1912, Henry Ford made possible mass production of automobiles at his Highland Park factory by introducing an assembly line production system. The introduction of mass production implies that production can be based on sales projections. Rather than producing on demand after an order has been received, it was now possible to mass produce on a schedule and sell all of the output. However, in order to keep the inventory of finished products low, it became necessary to develop marketing strategies as well as consumer financing systems such as monthly installment payment plans.

These industrial changes also brought about major social changes. With production based in large factories, working conditions changed. Although the specific problems differed among industries and enterprises, one might characterize the change as a general shift from indirect to direct employment. Under on demand production, the workload was quite variable and indirect employment was efficient, and skilled artisans hired helpers as needed and taught skills under an apprentice system. However, with the development of machines and tools, factory work depended less on the skills of artisans. By replacing general tools that can be used in many situations but required considerable skills to use with specialized machines that focused on a specific task and could be easily used by unskilled workers, assembly line production became possible.

In terms of industrial development in Japan, new industries were first introduced under the guidance of foreign engineers and technicians who taught them how to use the machines and run factories. However, as these technicians left, labor bosses who gained their work experience
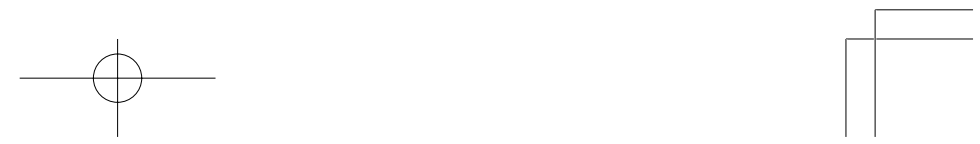
under the foreign technicians came to run the factory floor, in part because there weren't enough native university educated engineers who could manage the factories. Eventually, the labor bosses would contract with the factory to provide labor and complete a certain part of the production, and wages would be paid to the workers through their bosses. When there would be extra work, more labor would be brought in through other bosses. This represents a typical pattern of indirect employment. Such employment pattern often becomes exploitative of labor, and worker wages are low in part because the bosses take a cut. By the end of the nineteenth century, criticism over such working conditions became widespread throughout society, leading to the development of labor unions and a genre of literature called "proletariat literature."

Direct employment of unskilled labor developed in response to such working conditions and criticisms. One factor that made direct employment possible was the development of a cadre of managers with university education or foreign training who were able to design and manage factories. Another important factor in this transition is the development of managerial paternalism as the underlying philosophy.

The spread of managerial paternalism took place in Japan in the early part of the twentieth century. It progressed through various industries, beginning with chemicals, then textiles, heavy industry, mining, and construction. ${ }^{4}$ Under this philosophy, once employed, all workers become a part of the family. The senior management, as parents, must pay attention to the general living conditions and health of their "children" workers, and bear the responsibility of educating them. If the workers wanted to play baseball, then managements, as parents, must assist them. Such thinking led to the development of fringe benefits, corporate training and education programs, and eventually, corporate sports.

Of course, such development did not take place only in Japan. The changes in industrial structure that began in the late nineteenth century, often called the second industrial revolution, first took place in Germany and the United States. In terms of providing fringe benefits to the

4. Hiroshi Hazama, Nihon rōmu kanrishi kenkyū [A history of labor management in Japan] (Tokyo: Ochanomizu Shobō, 1978), 66. 


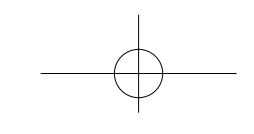

workers, the German steelmaker Krupp is well known. Alfred Krupp led the way in developing a fund for illness and pensions, and provided workers with dormitories and company housing. He encouraged the establishment of consumer cooperatives in his company housing complexes and sold groceries at low prices. For the enjoyment of his workers, he built beer halls, cafés, bowling lanes, and athletic grounds. For these efforts, Krupp received the Labor Welfare award at the Paris World Fair in $1886 .{ }^{5}$ Corporate sports teams were formed, as well, and legacies of such teams, such as Leverkusen ${ }^{6}$ in the German soccer league Bundesliga, still exist today. However, because the system of supporting sports is different, corporate sports did not develop as extensively as it did in Japan.

In the United States, the policies implemented by Henry Ford are well known. Chūma Hiroyuki comments on Ford's policies as follows:

In sum, these employment policies produce workers who live in company housing, receive medical care from company doctors, attend company schools, play on company sports teams, buy company stock, and are represented by company-based labor unions. $^{7}$

This description would work well as a summary of the traditional "Japanese management" as well.

The Greater Japan Tokyo Baseball Club [Dainihon Tokyo Yakyū Kurabu], founded in 1935 and known as the Tokyo Giants, ${ }^{8}$ went on a barnstorming trip throughout the United States shortly thereafter and played against teams from General Motors and Ford in the Detroit suburbs. The Tokyo Giants played 105 games on this barnstorming trip with a record of 75 wins, 33 losses, and one tie. Most of their opponents were semi-professional teams, but a few were corporate

5. Yōko Tanaka, Doitsu kigyō shakai no keisei to hen'yō [Formation and change in German corporate society] (Kyoto: Minerva Shobō, 2001), 31-33.

6. Turn und Sportverein Bayer 04 Leverkusen was a corporate sports team originally founded in 1904 by the pharmaceutical firm Bayer AG.

7. Hiroyuki Chūma, “' 'Nihonteki’ koyō kankō no keizai gōrisei saikentō: 1920-nendai no nichibei hikaku no shiten kara [A reconsideration of the economic rationality of "Japanese style" employment practices: From the perspective of Japan-US comparisons in the 1920s]" Keizai kenkyū 38:4 (1987): 307-320.

8. This team eventually became the present day Yomiuri Giants of the Japanese professional baseball Central League. 
baseball teams. According to Nagata Yōichi, many well-known industrial enterprises of this era founded their own baseball teams which played in industrial leagues composed of other corporate baseball teams. These teams were founded for the same reasons the corporate sports teams were developed in Japan: to provide healthy recreation and entertainment and to build unity and solidarity among employees. The Tokyo Giants defeated the General Motors City Stars by the score of 11 to 7, and Ford V8's by the score of 6 to 0 . In the game against Ford, ace pitcher Sawamura Eiji pitched a completed game shutout, allowing only seven hits. 9

If these conditions were allowed to continue in the United States, perhaps it would have become a country in which corporate sports was prominent. However, passage of one piece of legislation changed the underlying conditions: the Wagner Act, which was passed in 1935. Wagner Act strengthened the rights of labor unions, and stipulated that if management provided additional benefits such as fringe benefits, training, or education to labor, the balance of power between management and labor would become uneven and the solidarity of the workers would diminish. The provisions of the Wagner Act were implemented in stages, and were later strengthened with the passage of the Taft-Hartley Act in $1947 .{ }^{10}$ As a result, corporate sports teams like the baseball teams at GM and Ford that played against the Tokyo Giants disappeared. In addition to corporate sports teams, corporate health insurance and pensions began to disappear as well.

The most enlightened of the Japanese entrepreneurs, such as Mutō Sanji of Kanegafuchi Spinning [Kanegafuchi Bōseki Kabushiki Kaisha], began to implement fringe benefit systems within their companies beginning in the 1890s, having emulated Krupp for their consumer cooperatives and National Cash Register (NCR) for corporate newsletters. $^{11}$ And in 1914, the company established the Section to

9. Hiroya Nagata, Tokyo jaiantsu hokubei tairiku enseiki [A record of the North American tour of the Tokyo Giants] (Osaka: Tōhō Shuppan, 2007).

10. Hiroya Nakakubo, Amerika rōdōhō [American labor law] (Tokyo: Kōbundō, 1995), 315.

11. Yoshitaka Fujita, "Kigyō fukushi [Corporate welfare]" in Nihon rōmu kanrishi [History of Japanese Labor Management], vol. 1, Takeshi Chūjō and Kazuo Kikuno, eds. (Tokyo: Chūō Keizaisha, 1988): 144-5.
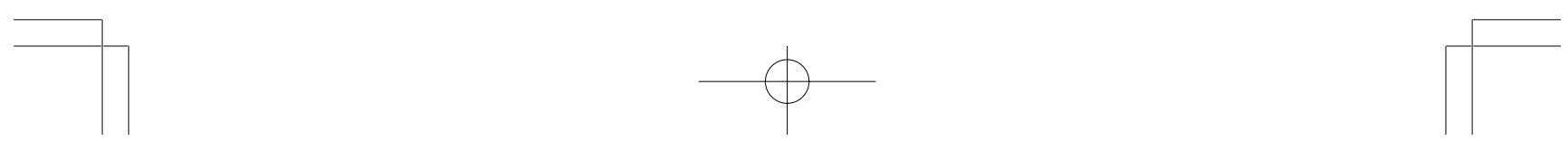
Increase Happiness [kōfuku zōshin kakari] in order to enhance fringe benefits. Corporate sports developed in such context. As Japan followed Germany and United States as models in developing fringe benefits, education, and training, it also attained, at the beginning of the twentieth century, the basis for corporate sports.

\section{THE DEVELOPMENT OF CORPORATE SPORTS}

While corporate sports originated as a human resource management policy, it gained additional meanings and changed according to the times throughout most of the twentieth century in Japan. All the while, corporate sports supported sports in Japan. During the years when the rules defining amateurism in Olympic competition was very strict, athletes supported by the corporate sports system was occasionally derided as "corporate amateurs," in the way state supported athletes of the communist bloc were called "state amateurs." As long as the athletes had to maintain their amateur status, they were required to maintain work patterns as corporate employees, such as working in normal jobs in the morning. However, as the Olympics became more commercialized beginning with the Los Angeles summer games in 1984 and restrictions on amateur athletes were relaxed, the number of athletes for whom sports became their primary occupation increased dramatically. One contributing factor in this development was the addition of foreign athletes to strengthen corporate sports teams in various team sports, made possible by the favorable exchange rate. In other words, more corporate sports teams became closer to the advertising model.

Although an in-depth discussion of amateurism is outside the scope of this article, it should be noted that there is a large gap between the conceptualization of amateurism between Europe and Japan. In order to be recognized as an amateur athlete in Japan, it was necessary for athlete-employees to work, even if part time, especially considering their post-retirement career. It was a beneficial both for the athleteemployee as well as the company that wanted to diversify its workforce.

However, as the restrictions on amateurism are loosened, a new type of corporate sports that is completed unrelated to human resource management began to be prominent. First, employee-athletes who were 
contract employees and not regular employees increased substantially, especially in female sports teams. This new type of employee-athletes do not work regular jobs at the company and retire from the company when their sports careers end. Employees support corporate sports athletes because they are their colleagues. On the other hand, if company's support is primarily financial, then such support only serves to advertise the company. If corporate sports are merely advertising, then companies withdraw support without much thought during times of economic duress. In these ways, corporate sports are used and discarded.

It is not the purpose of this article to criticize corporate support of sports for the purpose of advertising. There is a long history of such support for sports in Japan. For example, the Tenkatsu Baseball Team [Tenkatsu Yakyüdan], founded in 1921 as the second oldest professional baseball team, was established for the purpose of advertising, playing baseball games as the opening act of magician Shōkyokusai Tenkatsu. In the Inter-city Baseball Tournament [toshi taikō yakyū], Columbia Record Company's baseball team participated actively both before and after World War II. In the postwar years, many cinema production companies owned professional baseball teams. ${ }^{12}$ As long as corporate participation contributes toward the development of sports, the purpose behind their participation is irrelevant.

However, there are examples of corporate sports teams whose rise and fall are intimately tied with the economy. Women's volleyball teams sponsored by supermarkets are classic examples of corporate sports teams that rose with the Japanese economic bubble of the 1980s and disappeared when the bubble burst. Daiei Orange Attackers and Itō Yōkadō Prior, sponsored by supermarket chains Daiei and Itō Yōkadō, respectively, entered the women's volleyball Japan League in 1982, became contenders in the Japan League and its successor V League, and withdrew from the V League around 2000. As an industry, supermarket chains employ mostly part time workers, and have little to offer in fringe benefits or education and training. Thus the need to sponsor corporate sports teams as a human resource management strategy is low.

12. Masahiko Sawano, "Toshi taikō yakyū to kigyō [Inter-city baseball tournament and corporations] Hokkai gakuen daigaku keiei ronshū 6:4 (2009): 137-148.
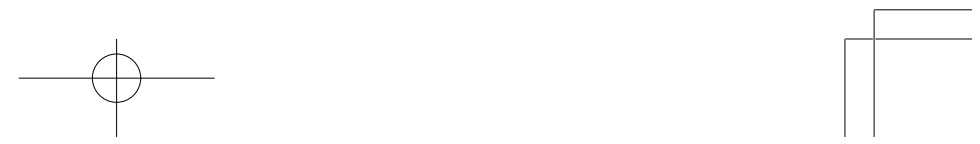


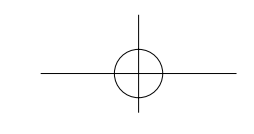

These teams began as recreational teams for employees, and became semi-professional teams for the purpose of corporate advertising when they began to win. When the regulations on amateurism were relaxed, these teams brought in foreign athletes to strengthen the team, and disbanded when the economic bubble burst. Because they were perennial contenders for the league championship, the damage to the league and the sport was significant.

In term of the impact of corporate teams on the sport itself, the case of American football is significant. As key businesses in small and medium cities, regional banks have supported sports. Their role in support of sports had been especially significant as their region was selected to host the National Sports Festival, whose host prefecture rotates around the country each year. Regional banks often established teams in sports that had not been popular in the region in preparation for the National Sports Festival.

On the other hand, large national banks, called city banks [toshi ginkō] in the Japanese banking industry, were generally not involved in corporate sports, and only those that had significant regional ties, such as the Daiwa Bank, Ltd. [Daiwa Ginkō], located in Osaka, and the Hokkaido Takushoku Bank, Ltd. [Hokkaido Takushoku Ginkō], ${ }^{13}$ located in Hokkaido, were the exception. However, in the 1980s, the large national banks also began to establish corporate sport teams with the generous profits from the bubble economy. A good example of this development took place in American football, where major city banks, including Tokyo-Mitsubishi, Sanwa, Sakura, Tōkai, and Sumitomo, all established teams in the $\mathrm{X}$ League. But as the post-bubble recession worsened, all of these teams withdrew from the league, beginning with Tōkai and Sumitomo in 1998. Tokyo-Mitsubishi and Sanwa held out the longest, but in 2000 , their teams withdrew as well, leaving no banksponsored team in the league.

The banking industry itself went through a major reorganization shortly thereafter, and none of the banks named in the previous paragraph remain today in the same form. Thus, the withdrawal of bank-sponsored teams was inevitable. However, it is important to note

13. Hokkaido Takushoku Bank supported a wide variety of sports, and the impact of its bankruptcy on the Hokkaido region as well as winter sports was very significant. 
that the large national banks had another significant impact on corporate sport through the companies to whom they made loans. The banks forced these companies to restructure their businesses as a condition of continuing their loans, and often included the disbanding of corporate sports teams as one of the conditions. In these ways, the post-bubble recession and the reorganization of the banking industry that followed had caused significant damage to corporate sports. ${ }^{14}$

\section{THE DISINTEGRATION OF CORPORATE SPORTS}

In the short term, the advertising model of corporate sports support is more than adequate in ensuring survival of the sport itself. However, in making any long-term investment in sports such as increasing competitiveness or opportunities for participation, the human resource management model of corporate sports support is more appreciated by the sports community. However, changes in the economy and the society are making the human resource management model of support more difficult.

One important factor in this societal change is the deregulation of employment practices. In 1992, the Labor Dispatch Law was implemented, legalizing temporary staffing and labor dispatching services. Over the years, the job categories eligible for dispatched labor have expanded. As a result, new class of the working poor, who work these short-term dispatch positions and are unable to land permanent jobs have emerged. Sudden termination and non-renewal of dispatch agreements have become a social problem. Some critics have characterized these conditions as a return of the labor conditions from the early twentieth century, and bestsellers from the period, such as Kobayashi Takiji's novel The Crab Cannery Boat [kani kōsen], have become popular again. As direct employment, one of the bases of corporate sports, disintegrates, it becomes impossible to sustain corporate sports.

However, simply returning to the earlier times by reinstituting tighter regulations would not necessarily lead to the revival of corporate sports, because the overall industrial structure of the Japanese economy has

14. Sawano, Kigyō supōtsu, 150.
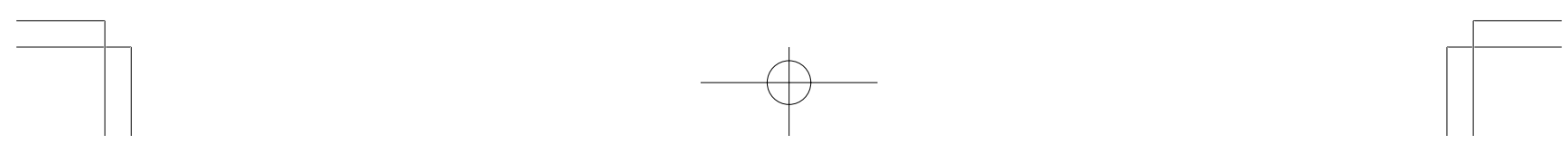
shifted dramatically. Sometimes called the Third Industrial Revolution, these structural changes, characterized as "more software," "more service," and "more information," have changed the way people work.

The need for skilled labor has declined significantly. For example, in an automobile factory, day-to-day work revolves around computers and robots, rather than the factory foreman. Hand flags and whistles that used to signal problems and to stop the assembly line have been replaced by sensors that automatically sense problems and stop the line. Under such system, characteristics that used to be valued in the factory, such as teamwork, knowledge, experience, and ingenuity, are no longer necessary. Instead, as long as the computer programs work correctly and the sensors are accurate, the workers only need to watch the displays, move equipment and supplies, and perform other light labor according to the computer instructions. Furthermore, industrial robots are beginning to replace people in performing these activities. For these reasons, indirect employment and short-term contract labor with minimal training have experienced a revival. If indirect employment becomes prevalent, there is little room for corporate sports as a solution to labor problems.

Another factor that has increased the difficulty for companies to own corporate sports teams is the change in the perception of who the main stakeholders of the company are. Management textbooks used to teach that the purpose of the corporation was survival and growth. If the company were to fail or stagnate, employees and customers would suffer as a result. However, in recent years, the purpose of the corporation is the maximization of the value of the corporation. In other words, the main stakeholder of the corporation has shifted from the employee to the stockholder. Some self-interested stockholders have begun to demand that instead of investing in corporate sports teams, employee fringe benefits, or education and training, corporations should increase dividend payments to stockholders.

In fact, the advancement in technology has eliminated the conditions that required companies to provide education and training to their employees, and employees have begun to demand that fringe benefits be paid directly to them, instead of the company investing in sports teams and sports facilities. As a result, companies have eliminated group recreational trips organized by each office section, sold off lodging 
facilities in seaside and mountain resort areas, and stopped holding sports field day. Many companies now find the property tax liabilities for their sports facilities to be too burdensome and have transferred them to local governments or sold them off altogether. In these ways, corporate sports have become unsustainable.

\section{CONCLUSION: THE FUTURE OF CORPORATIONS AND SPORTS}

The decline of corporate sports in recent years is analogous to the rise of corporate sports at the turn of the twentieth century in reverse. In addition to corporate sports, employee fringe benefits and in-house education and training have begun to disappear. One might characterize such development as following in the footsteps of the United States one century later. But these developments have had a significant impact on not only the corporate world, but have forced the reorganization of the national system of social welfare and education.

The future of corporate sports as a way to support Olympic medal contenders or internationally competitive teams is not viable for much longer because the corporate structure and function have fundamentally changed. Changes in rules and financial support may reverse these changes on the surface, but these changes in the corporate system are likely irreversible.

The nature of sports, especially at the internationally competitive level, has changed dramatically as well. In order to maintain top form in international competition, athletes need to train year-round and compete on the World Cup circuit. From the athletes' perspective, having to spend time working at a company, even on a limited basis, is an obstacle that their competitors do not have.

Corporate sports, however, are still meaningful as a way to support participation and to expand opportunity. For example, there used to be about three hundred corporate baseball teams throughout Japan. These teams played an important role as a place for those who played baseball in high school and college and wanted to continue to play after they completed their education. However, the number of corporate baseball teams has now been reduced to about eighty. With the suspension of the Nissan Motor team, the number of teams is predicted to decline further.

Because baseball is considered a national sport and widely accepted 
among the people, independent baseball leagues that have been formed in recent years have supplemented the decline of the corporate teams. However, playing on the independent league teams requires taking on a part-time job to supplement the meager salary as a ball player. Unless one is good enough to move on to a professional team, players need to find a job on the job market once their playing career is over. These retired athletes are older in age and do not have any work experience, making them less competitive in comparison to the new graduates. If they had played on corporate teams, they would have learned some jobrelated skills and would have been able to work at the same company after their retirement as athletes.

Support for the less popular sports in small and medium cities outside of the major urban areas is another area with growth potential. Historically, corporate sports have been more active outside of the major urban areas, with the exception of Osaka, which was one of the major centers for textile factories. For example, Nippon Steel's rugby team was located at Kamaishi (Miyagi prefecture), and the track and judo teams of Asahi Kasei were based in Nobeoka (Miyazaki prefecture) in Kyushu. In the large urban cities, there are many opportunities to participate in sports besides the company. However, outside these areas, companies play a much bigger role in the local community. For the company, supporting sports in these instances become important community contribution.

One good example of regional companies making community contribution through sports can be found in Usuki (Oita prefecture) in Kyushu. A regional brewing company called Fundōkin Soy Sauce Company [Fundōkin Shōyu] established a tennis team when Oita prefecture was selected to host the National Sports Festival, and the team has since become a regional powerhouse. ${ }^{15}$ In Hokkaido, a household fixtures company based in Asahikawa called Kishii has a competitive basketball team. ${ }^{16}$ Both companies claim that their support of the sport teams is indispensable for their employees to feel good about working for the company, and that the sports teams strengthen their sales ability. In their respective local communities, the teams are

15. Ibid., 143-4.

16. Sawano, "Soshikiryoku," op. cit., 14-7. 
considered the company's contribution to the local area, and help increase participation in the sport by involving the children in the area. They also provide opportunities for athletes who played tennis or basketball in college to continue playing after graduation.

Companies such as Toyota and Panasonic with an impeccable balance sheet with little or no bank loans on the books and with little fear of takeover by a competitor may continue to maintain corporate sports teams. However, even in these cases, the advantage, from the perspective of traditional human resource management strategies, of having one has declined significantly. Not only have the structure of corporate organization changed, the attitudes of athletes have changed as well. The only reasons to continue to support sports that are still viable are contribution to the society at large and general support for sports. Even if these are the reasons for supporting sports, poorly performing companies, as in the case of Nissan, may not be able to maintain their support.

Major regional companies may be able to provide more support for sports in the future than large national companies who need to pay attention to their various stakeholders. For small and medium regional companies, the national social networks that are developed for participating in sports over a long period can be powerful in the development of new products and new customers. Increase in the number of such companies supporting sports would increase participation and strengthen competition at the top level.

A good example of such company is a geological survey company called Daichi, located in Toyama. A small company with about forty employees, Daichi became nationally known during the winter Olympics in Vancouver in 2010 because the speed skaters Maki Tabata and Masako Hozumi, who won the silver medal in women's team race, are members of this company's skating team. Daichi's skating team includes one other athlete, but since the two medal winners and their coach receive support from the Japan Skating Federation as Olympiclevel athletes, the company pays very little beyond their salaries. The largest expenses are for the third, younger athlete and the travel for the company president, who travels with the team to overseas competitions. Although they were unable to go to Vancouver, almost all of the employees went to Turin for the previous winter Olympics to support
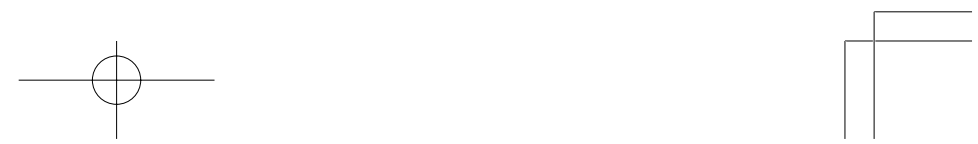
their team.

Such way of supporting sports is effective, especially at a time when many Olympic-level athletes have a hard time finding employment and paying for basic living expenses. At Daichi, the athletes come to work only on important ceremonial occasions, but every time one of their athletes perform well in competition, all of the employees are excited. A small regional company may not become nationally well known and competitive with a baseball or soccer team. However, if small companies within a region can support one or two athletes according to their abilities, then the region can support a team-based sport as well as an individual sport without placing a significant burden on any single company.

If the sole purpose of supporting sports is to strengthen the competitiveness of the top-level athletes in order to win the gold medal at the Olympics, then one way to do so might be to change the laws and support athletes as a government function. However, in order to maintain a national team that is a strong competitor internationally for the long term requires wide participation in the sport throughout the country, numerous teams that compete regionally, encourage children to participate, and to develop a system to identify promising athletes. In Japan through the 1980s, corporate sports supported such endeavor and provided the basic foundation for such a system. Today, however, with the exception of a few sports with well-developed professional leagues such as baseball and soccer, such system has disintegrated. The number of children who participate in sports has declined substantially. Local governments are strapped financially, and even if they had the human resources and the know-how to support sports programs, the public scrutiny of local government spending has increased. The role of companies in sports, instead of or in conjunction with local governments and their constraints, is still quite large.
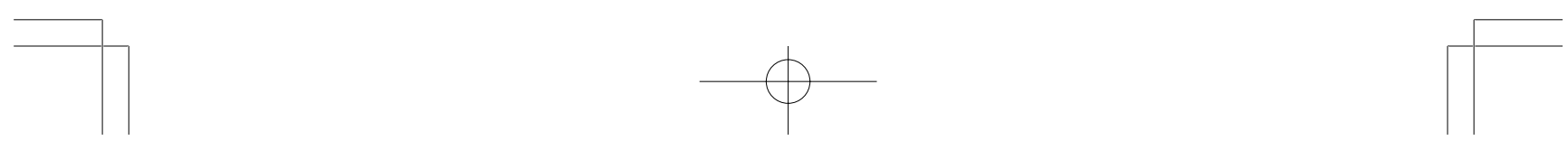